\title{
Mitä aikuiskasvatustutkimus on?
}

\begin{abstract}
Suomessa keskustellaan väliin kärjekkäästikin siitä, mitä aikuiskasvatustutkimus oikein on ja millaista tutkimusta laajenevalla aikuisopiskelun kentällä tulisi tehdä. Yhtäältä halutaan ylläpitää ja kehittää tutkimuksen keinoin vapaan kansansivistystyön perinnettä. Toisaalta ollaan kiinnostuneita satsaamaan entistä enemmän tutkimusresursseja työelämään liittyvään ammatilliseen aikuiskoulutukseen. Jotkut ovat kiinnostuneita aikuisten oppimisprosesseista ja opinkäynnin yksilöpsykologisista lähtökohdista. Mutta aikuiskoulutuksen ekspansio suorastaan pakottaa tutkimaan myös aikuiskoulutuksen yhteiskunnallisia yhteyksiä taloudesta politiikkaan.
\end{abstract}

Osa tutkijoista suosii välitöntä hyötyä lupaavia kokeilu- ja kehittämishankkeita, toiset lähinnä perustutkimusta. Jotkut tahtovat aikuiskoulutuksesta oman tieteenalansa, monet pitävät sitä osana kasvatustieteitä tai yhteiskuntatieteitä. Usein näissä vastakkainasetteluissa vastapuolen koetaan ymmärtävän väärin perus- ja soveltavan tutkimuksen, koulutuksen sekä kokeilu- ja kehittämishankkeiden keskinäissuhteet.

Kuten Aikuiskasvatuksen Tutkimusseuran esimies Antti Kauppi (1995, 3) toteaa, tuskin kenelläkään on selkeästi jäsentynyttä käsitystä siitä, miltä aikuiskasvatuksen nimissä tehty tutkimus kokonaisuudessaan näyttää. Yhtä mieltä tunnutaan kuitenkin olevan siitä, että aikuiskoulutuksen painoarvo on kohoamaan päin ja alaa tutkitaan liian vähän. Huolta kannetaan myös aikuiskoulutustutkimuksen tasosta, tieteen kehittymättömyydestä, teorian puutteesta. Aikuiskoulutuksen tutkimus on vielä paljolti lapsen kengissä" (vrt. Vaherva, 1986b, 490); maailmalla puhutaan "käsitteellisestä erämaasta", "tutkimuksen heikosta varustuksesta", "miltei olemattomuudesta", "raajarikkoisuudesta", "horjuvuudesta" ja "tarkoitushakuisuudesta". (Ks Nordhaug, 1986; Kivinen \& Rinne 1990) Yritykset teoriamallien hakemiseen ovat jääneet vaisuiksi (vrt. Rinne, Kivinen \& Ahola, 1992; Jarvis, 1987). (ks. myös viite 2 artikkelin lopussa).

Tässä artikkelissa tarkastellaan sitä, minkälaista aikuiskoulutustutkimusta Suomessa on harjoitettu, mihin kasvatustieteen osa-alueisiin tutkimus on pääsääntöisesti kiinnittynyt sekä miten se suhteutuu aikuiskasvatuksen ja aikuiskoulutuksen väliseen joskus kärkeväksikin koettuun dilemmaan. Emme tyystin väistä ottamasta kantaa myöskään tulevaisuuden pulmiin. (Viite 3).

jo 1960-luvulla perinteisten kansanvalistajien nähtiin muuttuneen markkinamiehiksi ja alan laitosten ajautuneen markkinamekanismien armoille. "Yleisön kosiskelusta" ja "kysynnän myötäilystä" oli tullut menestymisen ehto, väitettiin. (Tervonen, Salmela \& Rinne 1992, 35; vrt. Helminen, Jalonen \&Valkama, 1975). Viime aikoina tämä tendenssi näyttää vahvistuneen. 1980-luvun loppupuolella saatettiin todeta (Vaherva 1986b, 487):

"Emme mahda mitään sille, että hyötynäkökohtia ja taloudellisia arvoja ja kehitystä painottavassa yhteiskunnassa sellainen koulutus saa etusijan, jolta voidaan odottaa taloudellista tuottoa tehdyille investoinneille. Meidän on otettava tosiasiana, että ammatillisella aikuiskoulutuksella tulee olemaan etusija kehittämishankkeissa."

\section{Aikuiskasvatustiede vrs. kasvatustiede}

Aikuiskasvatustutkimuksen suomalaiset juuret juontavat Kansansivistysopillisen Yhdistyksen (1940) ja sen vuosikirjojen (1942) synnyttämiseen (Alanen 1991). Alan varsinainen akateeminen koulutus alkoi 
Tampereella vuonna 1965. jo tätä ennen, vuonna 1946 oli Yhteiskunnalliseen korkeakouluun saatu Pohjoismaiden, Aulis Alasen mukaan ehkä Euroopankin ensimmäinen "kansansivistysopin" professuuri. Seuraava, tällä kertaa "kasvatustieteen, erityisesti aikuiskoulutuksen" oppituoli perustettiin Helsingin yliopistoon vuonna 1980. Professuurien nykymäärän nostaa viiteen Jyväskylän, Turun ja Lapin yliopistoihin kuhunkin hieman eri nimikkeillä 1990-luvulla perustetut virat.

Muissa Pohjoismaissa vastaavaa kasvua ei näytä tapahtuneen. Tanskan ainokainen professuuri on pystytetty vuonna 1946, Ruotsin 1982 ja Norja pohdiskelee vielä sitä, olisiko aikuiskasvatus ylipäätään kasvatustieteestä ja yhteiskuntatieteestä erillinen opinala omine oppituoleineen. (Rinne 1993).

Tähänastisen aikuiskasvatustutkimuksen on sanottu paljolti olleen nykytilaa säilyttämään pyrkivää tutkimusta. Tapio Vahervan (1986a, 135) mukaan ainakin 1980-luvun alkua luonnehti status quota korostava konsensusparadigma.

Aikuiskasvatuksen tutkimus ponnistaa samasta kasvualustasta ja teoriapohjasta kuin kasvatustiede, perimmältään siis yhteiskunta- ja humanistisista tieteistä. Yhtenäiskoulu-uudistuksen jälkeen ekspansoitunut kasvatustiede ei kuitenkaan ole ollut järin kiinnostunut koululaitoksen ulkopuolisen aikuiskasvatuskentän yhteiskuntapainotteisesta tutkimuksesta. Ainakin vielä 1980-luvulla "kasvatustieteen ainelaitoksia ja valtakunnallista tutkimuslaitosta voidaan osoittaa syyttävällä sormella aikuiskoulutuksen kehittämistä koskevan tutkimustyön laiminlyömisestä" yleisen kasvatustieteen puolestaan askaroidessa 1ähes kokonaan koulukasvatuksen ja lapsi- ja nuorisoikäluokkien ongelmien parissa" (Vaherva 1986b, 490). Mutta myös aikuiskasvatus on kasvatustieteen tavoin loitonnut etäälle emotieteistään sekä hallinnollisesti että tutkimuksellisesti. Ilmeisesti tässä ollaan tekemisissä edellä viitatun enemmän tai vähemmän julkilausumattoman konsensuaalisuuden, jos kohta myös kentän oman "kehittämisideologian" kanssa.

\section{Tutkimus pitkään vähäistä ja laadultaan vaihtelevaa}

Väitöskirjoja suomalaisen aikuiskasvatuksen alalta on ilmestynyt niukanlaisesti, pitkään vähemmän kuin esimerkiksi yhden oppituolin Ruotsissa. Ensimmäinen suomalainen väitöskirja oli vahvasti sosiologinen ja historiatieteellinen. Kansansivistysopin varhaisin tohtori vastikään edesmennyt Kosti Huuhka väitteli vuonna 1955 aiheesta Talonpoikaisnuorison koulutie. Tämän jälkeen ovat itse Tampereen oppiaineessa väitelleet mm. Aulis Alanen (1969), Juhani Honka (1984), Eero Pantzar (1985) ja Jukka Tuomisto (1986). Omat kynänjälkensä tutkimusten henkeen ja suuntautumiseen piirsivät professorit Urpo Harva, Matti Peltonen ja Aulis Alanen. Vuoden 1979 Tampereen virkaanastujaisesitelmässään Matti Peltonen asetti tavoitteeksi vähintään kymmenen hyvätasoista väitöskirjaa vuoteen 1985 mennessä. Tavoite ei tainnut aivan toteutua.

Helsingin oppituolin perustaminen on toki sittemmin lisännyt tulevien väittelijöiden lukua, kuten 1990-luvun tuoreet oppituolitkin varmasti tekevät. Siinä, missä Tampereen perinne rakentuu vapaaseen kansansivistykseen, näyttää Helsingin alaksi muodostuneen kehittävä työntutkimus ja metodologia. 1990-luvun suuntautumisiin palaamme hieman tuonnempana. Merkittävää kuitenkin on, että asiallisesti aikuiskasvatuksen tutkimusta ja väitöskirjoja voidaan tehdä monen muunkin tieteen alueella, kuten esimerkiksi sosiaalipolitiikan, sosiologian, psykologian, kasvatustieteen, kommunikaatiotieteiden ja jopa tekniikan alalta. Tieteen alarajat eivät tässä mielessä ole poissulkevia ja aikuiskasvatustutkimuksen kentän määritys kamppailut ovat koko ajan käynnissä.

Aikuiskoulutuksen tutkimus on Suomessa pitkään ollut paitsi vähänlaista, myös laadultaan vaihtelevaa. Monitieteelliset tutkimusprojektit ovat suhteellisen harvinaisia. Suomessa julkaistiin 1970- ja 1980-luvuilla noin 120 aikuiskasvatusmonografiaa, keskimäärin kuusi tutkimusta vuodessa. 1980-luvun raporttien vuosi vauhdiksi Vaherva $(1988,30)$ on puolestaan laskenut kymmenen. Monografioiden määrä alkoi kohota 70-luvun loppupuolella. Aikuiskasvatustutkimuksen vilkkain kausi ajoittuu näillä kriteereillä 1980-luvun alkuvuosiin. Vuonna 1982 valmistui maassa 15 monografiaksi luokiteltavaa aikuiskasvatustutkimusta; vastaavaan määrään ei ole sittemmin ylletty. 


\section{Painopisteet didaktiikassa ja kasvatussosiologiassa?}

Vaikka luokitukset eivät aivan yksiselitteisiä olekaan, monografioina julkaistujen aikuiskasvatustutkimusten painopiste oli 1970-luvulla selvästikin didaktiikassa (yli kolmasosa), kasvatussosiologiassa (runsas viidennes) ja -psykologiassa (vajaa kuudennes). Noin viidennes tutkimuksista oli tilastollisia ja muita selvityksiä. (ks. Vanttaja 1993).

Eri laitoksissa tehdyt aikuiskasvatustutkimukset erosivat toisistaan profiileiltaan. Tampereella tehtyjen monografioiden valtavirta oli

varsinkin 1970-luvulla kasvatussosiologista (kaksi viidesosaa), myöhemmin myös didaktisesti painottunutta (kolmasosa). Valtion koulutus- ja kehittämiskeskuksen tutkimuksista yli puolet suuntautui alkuvuosina didaktiikkaan. Muualla tehdyt (KATI- ja KOTI-tietokannoista poimitut) tutkimukset sijoittuvat pääasiassa didaktiikkaan (neljäsosa) ja sosiologiaan (neljäsosa). Suurin osa koulutustarvetutkimuksista ja tilastollisista selvityksistä tehtiin muualla kuin Tampereella tai VKK:ssa.

Yli puolet monografiatutkimuksista on kohdistunut vapaan sivistystyön alueelle. Ammatilliseen aikuiskoulutukseen suuntautui noin neljännes tutkimuksista, loppu viidennes yleisesti aikuiskoulutukseen.

Tampereella tutkimus siis lähti 1970-luvulla Yhteiskunnalliselle korkeakoululle ominaiseen tapaan liikkeelle "aikuiskasvatussosiologista" perspektiiviä painottaen. Perinne jatkui aina 1980-luvun puoleen väliin saakka, jonka jälkeen kasvatussosiologinen tutkimus näyttää romahtaneen. Didaktinen tutkimus on ollut vahvaa alusta asti, tullen 1980-luvun lopussa tutkimuksen pääalaksi. Muiden osa-alueiden osuus on ollut vähäistä ja hajanaista.

Jyväskylän yliopiston Kasvatustieteiden tutkimuslaitoksen kokoamaan kasvatuksen ja koulutuksen tutkimusrekisteristeriin 1990-luvun vaihteessa kirjatut meneillään olleet tutkimusprojektit osoittavat sosiologisen (vajaa kolmannes) ja didaktisen (neljännes) tutkimuksen säilyttävän asemansa, samalla kun psykologinen tutkimus olisi yleistymässä (viidennes).

\section{Aikuiskasvatustutkimuksen painottuminen muuttui}

Merkittävin muutos on kuitenkin se, että 1990luvulle tultaessa ammatillisen aikuiskoulutuksen tutkimus on volyymiltään ja suhteelliselta osuudeltaan rajusti vankkenemassa neljän tutkimusprojektin viidestä suuntautuessa ammatilliseen aikuiskoulutukseen ja vain yhden kymmenestä vapaaseen sivistystyöhön.

Muutos on todella radikaali, kun verrataan tilannetta 70- ja 80-lukujen vastaaviin osuuksiin. Vielä tuolloin vapaan sivistystyön osuus ylitti puolet ammatillisen aikuiskoulutuksen jäädessä vajaaseen neljännekseen.

Tutkimuksen painopisteen heilahdus vapaan sivistystyön alueelta ammatilliseen aikuiskoulutukseen on yhteydessä yhteiskunta- ja koulutuspoliittisiin päätöksiin ja suoranaisiin pyrkimyksiin vahvistaa työelämään suuntautuvan aikuiskoulutuksen hyötytavoitteista tutkimusta mm. Suomen Akatemian erillisen tutkimusohjelman avulla. Koulutuksesta on tullut tärkeä osa työvoimapolitiikkaa.

1970-luvulta lähtien suomalaisen työvoimapolitiikan perinteisen "lapio- ja korvauslinjan" haastajaksi nousi aktiivisen työvoimapolitiikan "koulutuslinja" (esim. Kalela 1988; Mikkonen 1994; Salmela 1992). Aikuiskoulutuksen on tarkoitus osaltaan edesauttaa työvoiman alueellista ja ammatillista liikkuvuutta. Etenkin Harri Holkerin sinipunahallituksen aikana maan tavaksi tuli vastata elinkeinoelämän rakennemuutoksiin lisäämällä ammatillista aikuiskoulutusta, yrittäjäkoulutusta ja työvoimapoliittista aikuiskoulutusta. Lisäksi on alettu Puhua oppisopimusjärjestelmän kehittämisestä. Viimeaikaisen suhdannetaantuman ja puolen miljoonan työttömän oloissa työministeriöstä on tullut keskeinen aikuiskoulu- 
tusministeriö, ja paineet vahvasti laajene-van työvoimapoliittisen aikuiskoulutuksen tutkimiseen ovat entisestään lisääntyneet.

Ammatilliseen aikuiskoulutukseen ja sen tutkimukseen panostamisen on nähty olevan keskeisin keino myös kansainvälisen kilpailukyvyn säilyttämisessä ja lisäämisessä. Koulutuspoliittinen keskustelu on tarkan markan oloissa itse asiassa paljolti rajoittunut työelämän tarpeita palvelevaan koulutukseen. Politiikka painottuu suuntaan, jossa kilpailukyvyn palauttamisen, tuotekehittelyn, rationalisoinnin, vaikuttavuuden ja hyödyn termit ovat korostetusti esillä. Vapaan sivistystyön tavoitteiden ja tehtävien jääminen taka-alalle näkyy myös tutkimusten suuntautumisessa.

\section{Mitä Aikuiskasvatus-lehti on kertonut tutkimusintresseistä}

Monografiatarkastelun ohella aikuiskasvatuksen painopistealueita voidaan jäljittää myös kasvatusalan aikakauslehtien artikkeleita analysoimalla. Kasvatus-lehden palstoilla aikuiskasvatusta on käsitelty onnettoman vähän. 1970- ja 1980-luvuilta, koko kahdelta vuosikymmeneltä löytyy 50 tekstiä, jotka voi hyvällä tahdolla lukea aikuiskasvatuskirjoitelmiksi. Näidenkin lähinnä erikoisnumeroista löytyvien suppeahkojen juttujen keskeinen sisältö on paljolti koululaitoskeskeinen opettajien täydennyskoulutus.

Vuonna 1981 synnytetty Aikuiskasvatus-lehti on - alan ainoana pohjoismaisena tieteellisenä julkaisuna - jo sellaisenaan osoitus kasvaneesta kiinnostuksesta. Lehti jatkaa kansansivistyksen vuosikirjan ja aikakauskirjan katkeilevaa perinnettä aina 1940-luvulta. Aikuiskasvatuksessa ilmestyvien artikkelien voi olettaa käsittelevän aikuiskasvatuksen keskeisimpiä aihealueita. (Viite 4).

Aikuiskasvatus-lehden 1980-luvun artikkelien pääpaino on aikuiskasvatussosiologiassa (kolmannes) ja aikuiskasvatuspsykologiassa (viidennes). Kun monografisista tutkimuksista yli kolmannes oli didaktisia, on Aikuiskasvatuslehden artikkeleista niitä osapuilleen seitsemäsosa.

Ehkä yllättäen vapaata sivistystyötä käsitteleviä artikkeleja oli niitäkin vain seitsemäsosa, ammatillista aikuiskoulutusta käsitteleviä sitä vastoin noin 40 prosenttia. Lähes puolet artikkeleista luokittuu monialueisiksi yleisartikkeleiksi.

Lehden artikkeleista puolet oli yliopistoväen kirjoittamia, neljännes kouluhallinnon tai muun julkisen sektorin edustajien tekemiä. Aikuiskasvatuskentän laitosten (vapaan sivistystyön järjestöt, yritysten koulutusorganisaatiot jne.) osuus oli seitsemäsosa. Ulkomaisten osuus oli monen muun tieteenalan aikakauskirjaan verraten korkea, mikä todistanee kotimaisten kirjoittajien vähyyden ohella aikuiskasvatuksen avoimuutta myös ulkomaisten mallien suuntaan.

Yli puolet kaikista yliopistojen/tutkimuslaitosten henkilöstön tuottamista artikkeleista tuli Tampereen yliopistosta. Tampereella on ollut alan hegemonia vähän samalla lailla kuin Jyväskylän kasvatusopillisella korkeakoululla aikoinaan kasvatusopin kentällä. Helsingin yliopistossa työskentelevät ovat kirjoittaneet joka viidennen ja Jyväskylän yliopistoon kuuluvat joka kymmenennen artikkelin. Teknillisen korkeakoulun ja Turun yliopiston edustajien osuus

oli 1980-luvulla kummankin viitisen prosenttia. Saman verran artikkeleista oli yhteensä Joensuun ja Oulun yliopiston, Åbo Akademin ja Lapin korkeakoulun henkilöstöön kuuluvien kirjoittamia.

Aikuiskasvatustutkimukseen ja sen ympärillä käytävään keskusteluun osallistujia voi toki ryhmitellä monella tavalla. Seuraavassa Aikuiskasvatus-lehden artikkelien kirjoittajat luokitetaan kolmeen intressiryhmään: hallinnon, käytännön ja yliopistojen edustajiin. Intressiryhmien väliset erot teemoissa ja kannanotot tutkimuksen suuntaamiseen näkyvät seuraavassa asetelmassa: 


\begin{tabular}{|c|c|c|c|}
\hline & HALLINNON EDUSTAJAT & $\begin{array}{l}\text { KENTÄN } \\
\text { EDUSTAJAT }\end{array}$ & $\begin{array}{l}\text { TIEDEYHTEISÖN } \\
\text { EDUSTAJAT }\end{array}$ \\
\hline $\begin{array}{l}\text { KESKEISET } \\
\text { TEEMAT }\end{array}$ & $\begin{array}{l}\text { - henkilöstökoulutus ja -koulut- } \\
\text { tajan ammatti } \\
\text { - jatkuva koulutus } \\
\text { - aikuiskoulutuksen suunnittelu } \\
\text { ja yhteiskunnalliset muutokset } \\
\text { - aikuiskoulutukseen osallistu- } \\
\text { minen } \\
\text { - aikuisten oppiminen ja opetta- } \\
\text { minen } \\
\text { - kansainvälistyminen } \\
\text { - aikuiskasvatustutkimus }\end{array}$ & $\begin{array}{l}\text { - aikuisten oppimi- } \\
\text { nen } \\
\text { - opettaminen, mo- } \\
\text { nimuoto-opetus } \\
\text { - vapaan sivistystyön } \\
\text { historia } \\
\text { - täydennyskoulutus } \\
\text { - kansainvälistymi- } \\
\text { nen }\end{array}$ & $\begin{array}{l}\text { - aikuiskoulutuksenyhteis- } \\
\text { kunnalliset kytkennät } \\
\text { - aikuiskasvatuksen vertailu } \\
\text { eri maiden välillä } \\
\text { - tutkimus- ja kehittämistoi- } \\
\text { minta } \\
\text { - aikuiskasvatuksen filosofia } \\
\text { ja historia } \\
\text { - aikuisten oppiminen ja } \\
\text { opetus }\end{array}$ \\
\hline $\begin{array}{l}\text { TUTKI- } \\
\text { MUKSEN } \\
\text { KOHDEN- } \\
\text { TAMIS- } \\
\text { TARVE }\end{array}$ & $\begin{array}{l}\text {-ammatillinen aikuiskoulutus } \\
\text { - koulutuksen tulevaisuus } \\
\text { - opetussuunnitelmien ja oppi- } \\
\text { materiaalien laadinta } \\
\text { - opetuskäytäntö } \\
\text { - koulutustarpeen arviointime- } \\
\text { todit } \\
\text { - aikuiskoulutukseen osallistu- } \\
\text { misen esteet }\end{array}$ & $\begin{array}{l}\text { - opetusmenetelmät } \\
\text { - opiskelumotivaatio } \\
\text { - aikuiskoulutukseen } \\
\text { osallistuminen } \\
\text { - koulutustarvetutki- } \\
\text { mus ja tarpeen arvi- } \\
\text { ointimetodit }\end{array}$ & $\begin{array}{l}\text { - aikuiskasvatuksen teoria- } \\
\text { perusta } \\
\text { - elämäntavan ja aikuiskou- } \\
\text { lutuksen välinen yhteys } \\
\text { - aikuiskoulutuksen yhteis- } \\
\text { kunnallisten kytkentöjen } \\
\text { kriittinen tutkimus } \\
\text { - koulutuskäytännön kriit- } \\
\text { tinen analyysi }\end{array}$ \\
\hline
\end{tabular}

Asetelma 1 . Intressiryhmien väliset erot artikkelien teemoissa ja tutkimuksen tarpeen määrittelyssä (muokattu Vanttajan 1993 tutkimuksen pohjalta).

Kukin intressiryhmä pyrki tuomaan esille oman erityisalueensa keskeisiä ongelmia. Hallinnon edustajat kirjoittivat runsaasti valtion henkilöstökoulutuksen ja koulutuksen suunnittelun ongelmista. Käytännön edustajat taas olivat kiinnostuneita erityisesti opetuksen ja oppimisen kysymyksistä. Tiedeyhteisön - paljolti tamperelaiset - edustajat ovat puolestaan halunneet tuoda erityisesti esille mm. aikuiskasvatustutkimuksen teorian kehittämistarpeen, vertailevan tutkimuksen sekä aikuiskoulutuksen yhteiskunnalliset yhteydet.

Tässä esitetyt lähinnä määrällisen sisällönanalyysin tulokset kertovat varsinkin didaktiikkaan suuntautuvan aikuiskasvatustutkimuksen voimistumisesta. Muita melkoisen voimakkaita aloja sinänsä vielä heiveröisellä kentällä ovat aikuiskasvatussosiologia ja -psykologia. Sosiologian voimaa suhteessa esimerkiksi kasvatustieteen yleisesti ottaen vähäiseen sosiologiseen painotukseen selittävät ilmeisesti ensisijassa itse tutkimuskohteeseen liittyvät seikat. Aikuisopiskelu ja -koulutus, kuten aikuisten elämäkin kytkeytyvät täysin toisella kiinteydellä työmarkkinoihin ja -elämään, vapaa-aikaan ja ylipäätään yhteiskunnallisiin tekijöihin kuin lasten koulumuotoinen kasvatus. Lisäksi perinne liittää aikuiskasvatustieteen ensisijassa Tampereen yhteiskuntatieteelliseen tutkimustraditioon. Uutta, ajan - sekä Tampereen yliopiston - henkeä ilmaisevaa onkin se, jos sosiologia todella saa tehdä tilaa esiintunkevalle didaktiikalle.

Ammatillisen aikuiskasvatuksen osuuden kasvu puolestaan kertoo tutkimuksen olevan vahvasti sidoksissa ellei peräti alisteinen yhteiskunta- ja koulutuspolitiikan muutoksille. Myös aikuiskasvatuksen tutkijoilla on taipumus herkästi reagoida koulutuspolitiikan alueella ilmeneviin sosiaalisiin tilauksiin.

\section{Työnjako etenee, kilpailu kiristyy 1990-luvulla}

\section{HELSINGIN YLIOPISTO}

Helsingin yliopistoon on 1980-luvun ja 1990-luvun mittaan kasautunut melkoinen joukko aikuiskasvatusta enemmän tai vähemmän sivuavaa tutkimusta. Alueelta ovat väitelleet mm. Yrjö Engeström, Reijo Miettinen, Ritva Lindroos, Urpo Sarala, Jyri Manninen, Juha Varila ja Pertti Törmälä. Kasvatustieteiden laitoksella on yksi alan oppituoleista nimikkeellä aikuiskoulutuksen professuuri ja myös apulaisprofessuuri, mutta alan tutkimusta tehdään muissakin yhteyksissä. 
1980-luvun lopulla Helsingin ja koko maankin aikuiskoulutuksen kentän tutkimuksessa ja kehittämisessä nousivat näyttävästi esiin ns. kehittävät työntutkijat. Kehittävä työntutkimus ei selkeästi asetu minkään yksittäisen tieteen-alan rajoihin, vaan korostaa poikkitieteellisyyttä (esim. Engeström 1995, 11). Lähestymistapa moni-ilmeisine käytännön kehittämisprojekteineen voidaan kuitenkin sijoittaa aikuiskoulutuksen kentälle keskeisinä kohteinaan aikuisten oppimisprosessit ja työssä kehittyminen.

Kehittävän työntutkimuksen perusta nojaa lähinnä Vygotskin, Leontjevin ja Lurijan alkuunsaattamaan kulttuurihistorialliseen toiminnan teoriaan, jossa yksilöt tekoineen nähdään kollektiivisessa toimintajärjestelmässä - lähinnä yhteydessä työhön. Työelämän aikuiskoulutuksen, opetuksen ja oppimisen kehittämisen lisäksi kyseisen tutkimussuuntauksen kasvualusta on sosiologisessa ja psykologisessa työntutkimuksessa. Etenkin 1990-luvulla suuntaus, tai sanotaan nyt oikein koulukunta on pureutunut yhä vankemmin empiirisiin kehittämistutkimuksiin, $\mathrm{mm}$. siivous-, terveys- ja oikeudenhoitotöiden kehittämisprojekteihin.

"Kehittävä työntutkimus on muutosstrategia, joka yhdistää tutkimuksen, käytännön kehittämistyön ja koulutuksen. Se on osallistuva lähestymistapa, jossa työntekijät analysoivat ja muuttavat omaa työtään." (Engeström 1995, 12). Suuntaus on rakentamassa teoriaansa ja käytäntöänsä organisaatioista, yhteiskunnasta ja kulttuurista alhaalta päin, toisiinsa kytkeytyvien toimintajärjestelmien verkkoina viitaten mm. symbolisen interaktionismin, etnografian, kognitiotieteen ja sosiolingvistiikan läheisyyteen (mts 234-235). Koulukunnan tämänhetkistä suuntautumista ja voimaa kuvannee mm. sen johtohahmon Yrjö Engeströmin aktiviteetti paitsi Helsingin yliopiston aikuiskoulutuksen apulaisprofessorina myös kommunikaatiotieteiden vierailevana professorina San Diegossa ja vuodesta 1995 akatemiaprofessorina Suomessa - toisena kasvatusalalla emeritusprofessori Annika Takalan taannoisen tutkijaprofessuurin jälkeen.

Helsinkiin on myös perustettu yksi kasvatusalan harvoista tutkijakouluista. Sen lähtökohdat nojaavat selkeästi kehittävään työntutkimukseen. Tätä kautta aikuiskoulutuksen alan väitöskirjojen lisääntyminen tulevaisuudessa on ilmeistä.

\section{Turun yliopisto}

Turun yliopiston kasvatustieteiden laitoksella samoin kuin Koulutussosiologian tutkimuskeskuksessa aikuiskoulutuksen tutkimus määriteltiin yhdeksi painoalaksi niinikään 1980-luvun lopulla. Turkulaisen tutkimuksen painopiste on ollut luonnollisesti aikuiskoulutuksen sosiologisissa tarkasteluissa. Tutkimuksissa on analysoitu maan aikuiskoulutuspolitiikkaa ja aikuiskoulutukseen osallistumista, osallistumisen syitä, esteitä, motiiveja ja vaikutuksia sekä väestön koulutuspreferenssejä historiallisissa ja yhteiskunnallisissa yhteyksissään.

Turkulainen aikuiskoulutustutkimus ei niinkään ole rientänyt tarjoamaan kehittämisvisioita, vaan analysoinut tilasto-, kysely- haastattelu- ja muidenkin yhteiskuntatieteellisten aineistojen varassa aikuiskoulutuksen tilaa. Eritoten tutkimuskohteena ovat olleet työn ja koulutuksen väliset suhteet, työelämän aikuiskoulutus, työvoimapoliittinen aikuiskoulutus ja korkeakoulujen aikuiskoulutus.

Turussa paraikaa täytössä olevan professuurin alaksi on määritelty niinkin kompromissialinen nimike kuin "kasvatustieteen, erityisesti aikuiskasvatuksen ja -koulutuksen" professuuri. Uunituore alan tuote Turussa on Kaarina Nurmen sosiaalipolitiikan väitöskirja "Miksi aikuinen opiskelee"?

\section{Jyväskylän yliopisto}

Niin kasvatustieteiden tutkimuslaitoksella kuin nyt uuden professuurin turvin kasvatustieteiden laitoksella harjoitettu jyväskyläläinen aikuiskasvatustutkimus on suuntautunut ennen kaikkea henkilöstökoulutuksen kenttään. Kiintoisaa on, että uuden professuurin alaksi määriteltiin muista uusista määritelmistä poiketen 
aikuiskasvatustiede, vaikka useat Jyväskylässä tuotetut tutkimukset ovat paljolti käsitelleet erilaiska työn ja organisaatioiden kehittämisen ideoita.

Aikuiskasvatuksen alueeltakin on jonkin verran väitelty, mainita voidaan esimerkiksi Jukka Koron ja Pirkko Remeksen väitöskirjat. Maan vanhimman kasvatustieteen keskuksen, Jyväskylän yliopiston profiili on perinteisesti kuitenkin piirtynyt Uno Cygnaeuksen 1860luvun seminaariperinteestä asti vankasti koulukasvatuksen ympärille. Esimerkiksi 1960-luvulla perustetun ja sittemmin suuresti laajenneen Kasvatustieteiden tutkimuslaitoksen toiminnot ovat ensisijaisesti liittyneet erilaisiin koulu- ja ammattikasvatushallituksen toimeksiantoihin, jolloin aikuiskasvatustutkimuksen perinne on ollut suureen massaan verraten vähäinen.

\section{Lapin yliopisto}

Lapin yliopistoon perustettu "kasvatustieteen, erityisesti aikuiskoulutuksen" professuuri hakee vielä täyttämättömänä aluettaan. Mikäli vastikään Lapissa hyväksytty Juha Suorannan väitöskirja "Tekstit, murrokset ja muutos" kertoo jotakin Lapin profiilista, on suosiossa ennen muuta metodologinen pohdiskelu aikuiskasvatuksen ja kasvatustieteen tutkimuskentällä: "...kasvatus on helppo hyväksyä yhdeksi ja vieläpä merkittäväksi todellisuuden piirikseen, mutta miten on kasvatustieteen laita? ... eikö kasvatustieteilijäksi itseään nimittävän olisi rakentavampaa pyrkiä oppimaan taitoa tai mielikuvitusta kasvatukselliseen näkemiseen kuin yrittää omistaa tutkimus- ja hallintopoliittista 'tiedettä'." (Suoranta 1995,11). Suoranta korostaa yhtenä, joskin jo Tampereella omaksumanaan metodologisena sitoumuksena ns. eläytymismenetelmää, vaikka ei aivan tunnustuskirjailijaksi asti tunnustaudukaan. Toki esimerkiksi Reijo Väärälän ammattikoulutusta ja kvalifikaatioita tutkiva tuore väitöskirjakin samaisesta yliopistosta tulee lähelle aluetta, ja varsin toisenlaisesta yhteiskuntatieteellisestä kehikosta.

\section{Tampereen yliopisto}

Kuten todettu, ei Tampereella ole aikuiskasvatuksen oppiaineissa tehty väitöskirjoja sitten Jukka Tuomiston ja Eero Pantzarin jo kymmenkunta vuotta vanhojen töiden. Hyvin lähelle aluetta sitä vastoin on tultu joissakin Tampereen kasvatustieteen 1990-luvun väitöskirjoissa, joista voi mainita Leena Lahti-Kotilaisen (1993), Kaisa Kautto-Koivulan (1993), Pentti Rauhalan (1994) ja Anja Heikkisen (1995) väitöskirjat.

Alan vanhin Urpo Harvan, Matti Peltosen ja Aulis Alasen hallinnoima kasvatustieteen oppituoli Tampereen yliopiston kasvatustieteiden laitoksella on sekin natissut täyttämättä jo muutaman vuoden. Vanhaan kansansivistyksen perinteeseen liittyen sekä alan professuuri että apulaisprofessuuri on määritelty kasvatustieteestä eriytyneen "aikuiskasvatustieteen" viroiksi. Muutama vuosi sitten Tampereella kuitenkin jo liudennettiin kasvatustieteen ja aikuiskasvatustieteen eroa ja siirryttiin yhteiseen tieteenalaohjelmaan. Nyt on tarkoitus jatkaa eteenpäin ja yhdistää oppiaineet.

Paraikaa Tampereella käynnissä oleva profiilien korottamiseen tähtäävä strategiatyö on kuitenkin muuttamassa piakkoin ilmeisesti täyttöön tulevan professuurin alaa "ammatillisen aikuiskoulutuksen" nimikkeen suuntaan. Näin Jyväskylän professuuri jäisi tällä haavaa maan ainoaksi aikuiskasvatustieteen professuuriksi. Ehkä tämä kertoo jotakin tutkimuksen muutossuunnista.

Niin tutkimus- kuin artikkelianalyysistä saatu 1970- ja 1980-lukuja peilaava tulos on Tampereen yhteiskunnallisen korkeakoulun kansansivistysopin ympärille rakentuneen tradition vankka asema koko aikuiskoulutustutkimuksen hallinnassa ja suuntaamisessa. Kasvatustutkimuksen lisääntyessä ja esimerkiksi Helsingin, Turun Jyväskylän ja Lapin yliopistojen aikuiskoulutustutkimuksen voimistuessa Tampereen valta-asema tulee väistämättä uhatuksi. Jyväskylän oli aikoinaan sallittava opettajakorkeakoulujen verkottuvan ja Helsingin ja Jyväskylän myöhemmin kasvatustieteiden laitosten leviävän yli Suomen niemen. (Ks. Kivinen \& Rinne 1994.) Nyt käydään reviiritaistelua "aikuiskasvatustieteen" alueella. 
Ehkä Tampere jonkin kaltaista omaa tutkimusprofiiliaan teroittaen ammattikasvatuksen suuntaan antaakin periksi ja mukautuu laitokseksi laitosten joukkoon. Kun Hannele Niemen johtama kasvatusalan arviointiryhmä ei kyennyt merkittäviä profilointeja aikuiskasvatuksen alalla aikaansaamaan, on kiintoisaa nähdä, miten kansallinen työnjako aikuiskasvatustie-teen ja sitä vastaavan akateemisen koulutuksen kentällä kireähkön korkeakoulupolitiikan oloissa lopulta tehdään. Kuka sen tekee, kuka saa keppiä ja kuka porkkanaa?

\section{Entä tulevaisuus?}

Siinä missä aikuiskoulutus on Suomessa lisääntynyt rajuun tahtiin, näyttää myös aikuiskasvatuksen tutkimukseen satsatun melko lailla etenkin 1980- ja 90-luvuilla, mikäli oppituoleja ja väitöskirjojen määriin on uskominen.

Tutkimuksen painopiste on siirtynyt selvästi työelämän aikuiskoulutuksen suuntaan. Tätä siirtymää ei voi selittää pelkästään "aikuiskasvatustieteen" tai vapaan kansansivistyksen perinteeseen ankkuroituneen aikuiskasvatuksen tutkimuksen uupumisella. Kysymys on myös siitä, ettei ammatillisesti eriytyvää koulutusta antavien oppilaitosten kykyyn tuottaa työelämässä tarvittavaa ammattitaitoa entiseen malliin luoteta. Koulutuksen ja oppimisen kehittämisen painopiste on siirtymässä työpaikoille. Pääosa tosiasiallisista ammattitaidoista on joka tapauksessa tuotettava yrityksissä niiden spesifeihin tarpeisiin eikä ikään kuin summanmutikassa työelämästä irrallisissa oppilaitoksissa.

Piileekö jokin syvempi koulutuspoliittisen ristiriidan siemen siinä, että Suomeen ollaan pystyttämässä yhä korottuvaan, yhtämittaisena pitenevään koulutukseen perustuvaa ammattikorkeakoulujärjestelmää paljolti vanhan ammattikoulun jatkeeksi samaan aikaan, kun tosiasiat puhuvat sen puolesta, että koulutuspolitiikan pitäisi saada työelämässä tapahtuvaa työn oppimista korostavia piirteitä. Miten voidaan varmistua siitä, etteivät ammattikorkeakoulut intoudu perusteettomasti jäljittelemään akateemisia toimintakäytäntöjä elävän työelämä-yhteyden kustannuksella? Maahan ei näet kaivata yhtään uutta pientä kvasiyliopistoa vailla tieteellistä pohjaa.

Suomessa on ainakin 1990-luvulle asti ollut enemmän tai vähemmän julkilausumattomana periaatteena tuottaa koulutuksen avulla valmiita ammattimiehiä ja -naisia ikään kuin valmiina odottaviin virka- tai palkkatyöpaikkoihin. Työn luonne on muuttunut sellaiseksi, että työn ja koulutuksen keskinäissuhteet vaativat uudenlaisia järjestelyjä. Näitä on etsitty $\mathrm{mm}$. Matti Pekkasen työllisyysryhmän mietinnössä muutama vuosi sitten ja kansliapäällikkö Pertti Sorsan uunituoreessa työllisyystoimikunnassa.

Jaakko Numminen nostaa kirjassaan Koulutuspolitiikan vaihtoehdot (1994, 132-134) pöydälle mm. seuraavat vanhan järjestelmän pulmat:

- ammatillinen koulutusjärjestelmä ei kykene reagoimaan riittävän nopeasti työelämässä tapahtuviin muutoksiin,

- ammatillinen peruskoulutus ei johda työelämän kannalta riittävän syvälliseen erikoistumiseen,

- ammatillisen koulutuksen sääntelyyn liittyvä päätöksenteko on hidasta ja tavoitteetonta,

- ammatillisen koulutuksen ja työelämän kytkentöjen riittämättömyyden takia ammatillisen koulutuksen opetussisällöt (ja opettajakuntakin) ovat pahasti vanhentuneita,

- erikoistavien koulutustarpeiden ennakointi ei ole mahdollista,

- työelämän erikoistuminen kehittyy yrityskohtaiseksi ja kiihtyvästi nopeammin kuin koulutuksen mahdollisuus seurata jälkiä,

- ei ole oikein, että yhteiskunta kustantaa yrityskohtaisen ammattitaidon.

Yksi iso asia tulevaisuudessa on maan ammattitaidon tuottamisesta koituvien kustannusten jakokysymys. Ammatillisen peruskoulutuksen kustannusten voidaan katsoa jatkossakin kuuluvan paljolti yhteiskunnalle, mutta erikoistavan usein yritysspesifejä taitoja tuottavan lisäkoulutuksen kustannuksien sälyttäminen ve- 
ronmaksajien kontolle ei ole perusteltua. Jatkossa on syytä jakaa kustannukset ns. kolmikantaperiaatteella yhteiskunnan, yritysten ja yksilöiden kesken.

Suomessakin aletaan pikku hiljaa ymmärtää se inhimillistä toimintaa syvältä luotaava perusasia, että koulutus on usein aivan eri asia kuin osaaminen; suurin osa oppimisesta kun tapahtuu joka tapauksessa työnteon kautta osana koko elämänkaaren prosessia. Tulevaisuudessa aikuiskoulutuksen tärkeys siis vain korostuu. Mitä tämä edellyttää 2000-luvun aikuiskoulutustutkimukselta, sen profiloitumiselta ja työnjaolta, on niin sanoaksemme tuhannen ECUn kysymys, johon vastaamaan olemme toki osaltamme tarvittaessa sekä halukkaita että valmiita.

\section{VIITTEET}

1. Artikkelin otsikosta: "Edes otsikon kirjoittaminen ei onnistu törmäämättä niin sanoaksemme paradigmaattiseen kiistaan "aikuiskoulutuksen" ja "aikuiskasvatuksen" keskinäissuhteista. Artikkelissa käytetään kumpaakin käsitettä. (Kirjoittajien huomautus)

2. Suomalaisen aikuiskasvatustutkimuksen teoriapohjan vankkuudesta käy kirjoittajien näkemysten kanssa dialogia Eero Pantzarin näkemys hänen tässä numerossa julkaistussa artikkelissaan, väliotsikon "Eurooppalaisen aikuiskasvatustutkimuksen taustaa" alla. (Toimituksen huomautus)

3.Tarkastelumme empiirinen osuus perustuu paljolti Markku Vanttajan (1993) Turun yliopiston kasvatustieteiden laitoksella tekemän tutkielman yhteydessä kerättyihin Suomen aikuiskasvatustutkimusta koskeviin aineistoihin. Aineistot muodostuvat maassa 1970- ja 1980-luvuilla tehdyistä aikuiskasvatuksen monografiatutkimuksista sekä artikkeleista. Analyysin kohteena ovat tieteelliset julkaisusarjat, KATI- ja KOTI-tietokannat, kasvatusalan tutkimusrekisteri sekä Aikuiskasvatus- ja Kasvatus-lehdet.

4. Mm. Aulis Alanen $(1991,41)$ peräsi Aikuiskasvatuksen Tutkimusseuran 50-vuotisartikkelissaan jonkinlaista kokonaiserittelyä tuolloin 10-vuotiaan Aikuiskasvatus-lehden osalta.

\section{LÄHTEET}

Alanen, A. 1991. Aikuiskasvatuksen Tutkimusseura 50vuotias. Aikuiskasvatus 11, 1, 43-45.

Engeström, Y. 1995. Kehittävä työntutkimus. Helsinki: Painatuskeskus.

Helminen, S., Jalonen, U. \& Valkama, H. 1975. Aikuiskouluttajan ammattikäytäntö. Tutkimus aikuiskouluttajan ammattikäytännön kehityksestä ja nykytilasta. Tampereen yliopiston aikuiskasvatuksen laitoksen tutkimuksia ja selvityksiä 6 .

Jarvis, P. 1987. Adult Learning in the Social Context. London, Croom-Helm.

Kauppi, A.. 1995. Aikuiskasvatuksen haasteet myöhäisessä. modernissa. Aikuiskasvatus 15, 1, 2-3.

Kivinen, O. \& Rinne, R.. 1990. (toim.) Korkeakoulut aikuiskoulutusmarkkinoilla. Koulutussosiologian tutkimuskeskuksen raportteja 4, Turun yliopisto, Turku.

Kivinen, O. \& Rinne, R.. 1993. Yliopiston Huomen. Helsinki: Hanki ja jää.

Mikkonen, L. 1995. Työvoimapoliittiseen aikuiskoulutukseen hakeutuminen ja koulutuksen kokeminen. Koulutusmotivaatio, koulutukseen kohdistuneet odotukset ja niiden toteutuminen. Työministeriön työvoimapoliittisia tutkimuksia 95.

Nordbaug, O. 1986 Adult Education in the Wefflare Slate.Institutionalization of Social Commitment. International Journal of Lifelong Education 5, 1. 45-5 7. 
Numminen, J. 1994. Koulutuspolitiikan vaihtoehdot. Helsinki.

Rinne, R., Kivinen, O. \& Ahola, S. 1992.Aikuisten kouluttautuminen Suomessa. Osallistuminen, kasautuminen ja preferenssit. Koulutussosiologian tutkimuskeskuksen raportteja 10, Turun yliopisto, Turku.

Rinne, R. 1993. Pohjolan aikuiskasvatustutkijoille vuosikirja. Aikuiskasvatus 13, 1, 66-67.

Salmela, H. 1992. Aikuiskoulutuksen laajeneminen ja tehtävien muotoutuminen. Lisensiaattitutkielma. Turun yliopiston kasvatustieteiden laitos.

Tervonen, S., Salmela, H. \& Rinne, R.. 1992. Aikuiskouluttajien akateeminen koulutus: Näkemyksiä ja kokemuksia Turun yliopiston aikuiskoulutuksen kokeilun pohjalta. Turun yliopiston kasvatustieteiden tiedekunnan julkaisusarja $B$ 37

Vaherva, T. 1986a. Aikuiskasvatuksen sosiologinen tutkimus. Aikuiskasvatus 6, 3, 132-136

Vaherva, T. 1986b. Aikuiskoulutuksen kehittäminen ja kasvatustieteellinen tutkimus. Aikuiskasvatus 6, 6, 48 \& 491.

Vaherva, T. 1988.Aikuiskoulutuksen tutkimuksen kehittäminen. Aikuiskasvatus 8,1, 29-32.

Vanttaja, M.. 1993. Aikuiskasvatuksen tutkimus Suomessa. Aikuiskasvatuksen historiallinen muotoutuminen ja tutkimuksen painopisteet vuosina 1970-1990. Kasvatustieteen pro gradu-tutkielma. Turun yliopiston kasvatustieteiden laitos. 